\title{
Bell pepper yield as a function of an alternative source of organic matter
}

\author{
'Federal University of Piauí, Floriano, Brazi \\ ${ }^{2}$ Federal University of Piauí, Bom Jesus, Brazil \\ 3State University of Piauí, Uruçuí, Brazil \\ *Corresponding author, e-mail: tamnata.alixandre@hotmail.com
}

Tamnata Ferreira Alixandre ${ }^{*}\left(\mathbb{0}\right.$, Adriana Ursulino Alves ${ }^{2}(0)$ Géssica Marafon ${ }^{2} \mathbb{B}$, Edson de Almeida Cardoso ${ }^{2}$, Maristela Caetano Gomes ${ }^{2}\left(0\right.$, Anarlete Ursulino Alves ${ }^{3}[$

\begin{abstract}
For a good development and a consequently high production, the bell pepper requires, among other conditions, satisfactory levels of soil fertility. In this perspective, this work aimed to evaluate the parameters of production and productivity of the bell pepper cultivar 'Casca Dura Ikeda' cultivated in field conditions, with different doses of buriti stem, in Bom Jesus, Piauí. The experiment was conducted at the Horticulture Department of the Campus Professora Cinobelina Elvas of the Federal University of Piauí (CPCE/UFPI). The experimental design was in randomized blocks with treatments distributed in plots referring to organic fertilization. There were five (5) doses of buriti stem $\left(0,10,20,30\right.$, and $40 \mathrm{tha}^{-1}$ ) plus an additional treatment (bovine manure and NPK mineral fertilizer), with four replications and an experimental unit consisting of twenty plants. The following variables were analyzed: number of fruits per plant, mean fruit length, basal diameter, mean thickness of the fruit pulp, mean fruit weight, production, and yield. We concluded that the yield attributes of the bell pepper cv. 'Casca Dura Ikeda' are influenced by organic fertilization, and production is increased by the buriti stem doses of $20+$ $\mathrm{ha}^{-1}$ and $30 \mathrm{tha}^{-1}$ and by the use of the combination of manure and mineral fertilizer.
\end{abstract}

Keywords: Capsicum annuum L., organic fertilization, Mauritia flexuosa, yield

\section{Introduction}

Bell pepper (Capsicum annuum L.) is one of the main vegetables cultivated in the world, ranking among the ten horticultural species of greatest importance in Brazil due to its high consumption and production in both mature or immature forms, as well as in the food industry, for the production of dyes (Jadoski et al., 2011).

It is a crop of tropical climate and with a very demanding characteristic regarding the chemical and physical characteristics of the cultivation medium, presenting a good response to organic fertilization and excellent yields that can be obtained by the association of organic and mineral fertilizers (Ribeiro et al., 2000; Sediyama et al., 2009). The performing of agricultural practices, such as fertilization, as well as its effect on mineral nutrition and production of bell pepper must be performed so that producers use the fertilizers in a more rationally and economically (Oliveira et al., 2016).
One of the most employed inputs in the production of horticultural crops, in terms of volume, are materials as a source of organic matter, used generally in doses above $20 \mathrm{tha}^{-1}$, depending on the characteristics and cost of the product, as well as its composition and the premise that it may or may not be used in association with another type of fertilizer (Mello et al., 2000). In a study performed by Sediyama et al. (2014), it was verified that the organic fertilization with the use of swine manure provides bell pepper plants with adequate nutritional state and productive potential, revealing to be an adequate nutrient source for the crop.

In this perspective, there is a strong association between nutrient absorption and plant development, with the yield being extremely dependent on this association and on the movement of nutrients within the plant (Sediyama et al., 2009). However, the application of fertilizers and correctives is an expensive agricultural 
practice that represents, on average, $23.4 \%$ of the bell pepper production cost (Ribeiro et al., 2000). The use of organic residues available on rural properties constitutes, therefore, an economically important nutrient source for reducing the costs with the acquisition of chemical fertilizers (Khaitov et al., 2019).

One of these inputs that can be used is formed from the decomposed buriti stem (Sousa et al., 2013). Buriti is a palm species that defines palm swamp environments, serving as a food and income source for rural communities (Resende et al., 2012). The buriti stem emerges, therefore, as an alternative for possessing a wide regional distribution, although few studies have been performed using it as a source of organic matter. Therefore, this work aimed to evaluate the production and yield parameters of the bell pepper cv. 'Casca Dura Ikeda' in field conditions under different doses of buriti stem, in the municipality of Bom Jesus, Piauí.

\section{Material and Methods}

The experiment was conducted in the field in the period from June to September 2012. The research unit is located in the coordinates $09^{\circ} 04^{\prime} 28^{\prime \prime}$ 'S and $44^{\circ} 21^{\prime \prime} 31^{\prime \prime}$ $\mathrm{W}$; the mean elevation is approximately $277 \mathrm{~m}$ above sea level, with a mean maximum annual temperature of 36 ${ }^{\circ} \mathrm{C}$ and a minimum of $18{ }^{\circ} \mathrm{C}$; the mean annual rainfall is $1200 \mathrm{~mm}$ (INMET, 2018). The soil of the experimental area is a Eutrophic Yellow Latosol, which presented, in the 0 to $20 \mathrm{~cm}$ layer, the following characteristics: Organic matter $=18 \mathrm{~g} \mathrm{dm}^{-3} ; \mathrm{pH}\left(\right.$ in $\left.\mathrm{CaCl}_{2}\right)=5.9 ; \mathrm{P}$ resin $=11 \mathrm{mg} \mathrm{dm}^{-3} ; \mathrm{K}=$ $2.8 \mathrm{cmol}_{\mathrm{c}} \mathrm{dm}^{-3} ; \mathrm{Ca}=75 \mathrm{cmol}_{\mathrm{C}} \mathrm{dm}^{-3} ; \mathrm{Mg}=15 \mathrm{cmol}_{\mathrm{C}} \mathrm{dm}^{-3}$; $\mathrm{H}+\mathrm{Al}=18 \mathrm{cmol}_{\mathrm{C}} \mathrm{dm}^{-3} ; \mathrm{SB}=92.8 \mathrm{cmol}_{\mathrm{C}} \mathrm{dm}^{-3} ; \mathrm{CTC}=110.8$ $\mathrm{cmol}_{\mathrm{c}} \mathrm{dm}^{-3} ; \mathrm{V}=83 \%$.

The material used as a source of organic matter was obtained from decomposed buriti stems originated from a moist forest region in the municipality of Palmeira do Piauí/PI, which were in the stage of full decomposition. The buriti stem presented the following characteristics: Organic Carbon $=341.8 \mathrm{~g} \mathrm{~kg}^{-1} ; \mathrm{C} / \mathrm{N}$ Ratio $=18.3 ; \mathrm{pH}=5.5$; $\mathrm{N}=18.7 \mathrm{~g} \mathrm{~kg}^{-1} ; \mathrm{P}=2.5 \mathrm{~g} \mathrm{~kg}^{-1} ; \mathrm{K}=8.5 \mathrm{~g} \mathrm{~kg}^{-1} ; \mathrm{Ca}=12.0 \mathrm{~g} \mathrm{~kg}^{-1} ;$ $\mathrm{Mg}=2.9 \mathrm{~g} \mathrm{~kg}^{-1} ; \mathrm{S}=2.2 \mathrm{~g} \mathrm{~kg}^{-1} ; \mathrm{B}=15.5 \mathrm{mg} \mathrm{kg}^{-1} ; \mathrm{Cu}=8.5 \mathrm{~g}$ $\mathrm{kg}^{-1} ; \mathrm{Fe}=1.0 \mathrm{~g} \mathrm{~kg}^{-1} ; \mathrm{Mn}=556.6 \mathrm{mg} \mathrm{kg}^{-1} ; \mathrm{Zn}=198.2 \mathrm{mg} \mathrm{kg}^{-1} ;$ Moisture $=39,1 \%$; Wet Density $=426.1 \mathrm{~kg} \mathrm{~m}^{-3}$; Total Porosity $=84.0 \% \mathrm{v} / \mathrm{v}$.

An experimental design in randomized blocks was employed, with four replications and treatments distributed in plots referring to the fertilization with five doses of buriti stem $\left(0,10,20,30\right.$, and $\left.40 \mathrm{tha}^{-1}\right)$ and a further treatment (tanned bovine manure and mineral fertilizer NPK). The experimental area was divided into 24 plots, containing 20 plants distributed in four rows of five plants. In order to minimize the interferences between treatments in the experimental plots, only the six plants located in the central rows were evaluated, with a useful area of $0.64 \mathrm{~m}^{2}$. The buriti stem obtained from the natural and total decomposition of the buriti palm was sun-dried and its incorporation to the plant bed was performed with the aid of a hoe, at the depth from 25 to $30 \mathrm{~cm}$.

The treatment that corresponded to the conventional fertilization was performed as a function of the soil analysis, using tanned bovine manure and the NPK mineral fertilizer according to the Recommendations for Fertilization and Liming for the State of Ceará, providing, at planting, $20 \mathrm{tha}^{-1}$ of incorporated cattle manure in the plant beds, ten days before transplantation, $40 \mathrm{~kg} \mathrm{ha}^{-1}$ of $\mathrm{N}, 220 \mathrm{~kg} \mathrm{ha}^{-1}$ of $\mathrm{P}_{2} \mathrm{O}_{5^{\prime}}$ and $120 \mathrm{~kg} \mathrm{ha}^{-1}$ of $\mathrm{K}_{2} \mathrm{O}$, as well as $50 \mathrm{~kg} \mathrm{ha}^{-1}$ of $\mathrm{N}$ and $60 \mathrm{~kg} \mathrm{ha}^{-1}$ of $\mathrm{K}_{2} \mathrm{O}$, via topdressing, divided into equal parts, at 30,45 , and 60 days after transplantation. Urea, single superphosphate, and potassium chloride were used as sources of $\mathrm{N}_{1} \mathrm{P}_{2} \mathrm{O}_{5}$, and $\mathrm{K}_{2} \mathrm{O}$, respectively. After soil analysis, it was verified that there was no need for liming.

The seedlings were produced in expanded polystyrene trays with 128 cells filled with the Tropstrato

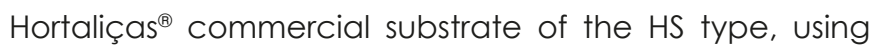
the 'Casca Dura lkeda' hybrid, and taken to the field at 46 days after sowing. Localized irrigation by dripping was employed with inline drip emitters (interior of the tube), drip tubes operating at a pressure of 7.2 m.w.c (meter of water column), and a nominal flow rate of $1.7 \mathrm{~h}^{-1}$, spaced at every $0.30 \mathrm{~m}$, with UV protection, a minimum of $1.8 \%$ of carbon black of adequate dispersion, 8.0 $\mathrm{mm}$, and internal diameter of $6.4 \mathrm{~mm}$, with one tube per planting row. A plate filter was used to avoid obstruction of the drip tubes and, consequently, a spatial variation in the irrigation water depth. Irrigation was performed twice a day in irrigation shifts, at the beginning and end of the day, with a mean time of daily irrigation of 30 minutes.

Weed control was performed through hoeing, especially at the beginning of the cultivation, a period in which there was more interference by weeds. There was no need for plague and disease control since there were no populations that could cause economic damages to the crop. The plants were conducted with three stems from the first bifurcation through weekly thinning interventions, so only the three stems were maintained. The plants were individually trained and tied by garden strings to avoid tipping and, consequently, the break of the stems due to the weight of the fruits, with trainers of $0.7 \mathrm{~m}$ of height fastened to the plant. 
The harvests were six in total, lasted for approximately 30 days, and were performed from 62 days after transplantation (DAT) when the fruits presented a bright green-colored surface. The harvests were individualized, occurring for the six marked plants in the experimental area. After the collection of the fruits, these were sent to the Laboratory of Food PhysicalChemical Analysis of the Federal University of Piauí, Campus Professora Cinobelina Elvas, for the evaluations of production.

The following variables were evaluated: mean fruit length $(\mathrm{C})$ : obtained by measuring the length of the harvested fruits and dividing it by the number of harvested fruits, with the aid of a digital pachymeter and expressed in $\mathrm{mm}$; basal diameter (D): obtained by measuring the diameter of the harvested fruits and dividing it by the number of harvested fruits, with the aid of a digital pachymeter and expressed in $\mathrm{mm}$; mean thickness of the fruit pulp (E): obtained with the aid of a digital pachymeter, graduated in millimeters. For that purpose, the harvested fruits were cut at the height of the upper-middle third and the pulp thickness was measured; number of fruits per plant (NF): the mean number of fruits per plant was obtained by summing the total number of harvested fruits and dividing it by the number of evaluated plants; mean fruit mass (M): obtained by summing the fresh mass of all fruits harvested weekly and dividing it by the total number of analyzed fruits, thus obtaining a mean fruit mass, expressed in grams (g); fruit production per plant (PROD): fruit production corresponded to the weighing of all harvest fruits divided by the number of evaluated plants, expressed in grams/plant; yield (PRODT): was obtained by summing the production of the six harvests, referring to the plants evaluated in the useful area, expressed in $\mathrm{kg} \mathrm{m}$ -2 and estimated for $t$ ha $^{-1}$.

The data were subjected to analysis of variance by the "F" test for the diagnosis of significant effect, whereas the doses of organic fertilization (buriti stem) were compared and subjected to a quantitative analysis of linear regression, according to the recommendations of Ferreira (2000). The Assistat computer software was used (Silva \& Azevedo, 2002).

\section{Results and Discussion}

It can be seen in Table 1 that there was no significant effect of the treatments that corresponded to the doses of buriti stem and bovine manure + NPK on the variables of mean fruit length, fruit diameter, and mean pulp thickness, which presented means of $70.9 \mathrm{~mm}, 40.18$ $\mathrm{mm}$, and $5.10 \mathrm{~mm}$, respectively. The low fruit development may have occurred due to the high temperature above the ideal $\left(19\right.$ and $21^{\circ} \mathrm{C}$ ) and also due to the low air relative humidity, which at flowering and fruiting were close $10 \%$. According to Finger \& Silva (2005), during the reproductive stage (flowering and fruiting) it is essential that the air relative humidity oscillates between $50-70 \%$. In this phase, the plants had difficulty in keeping turgid during the hottest part of the day, especially in hotter days, even with water available on the soil.

Table 1. Summary of the analysis of variance for the mean number of fruits per plant (NF), mean fruit mass (M), fruit production per plant (PROD), yield (PRODT), length (C), diameter (D), and thickness (E) of bell pepper fruits as a function of fertilization.

\begin{tabular}{|c|c|c|c|c|c|c|c|c|}
\hline \multirow{2}{*}{ Sources of variation } & & NF & $M$ & PROD & PRODT & C & D & $E$ \\
\hline & DF & \multicolumn{7}{|c|}{ F test } \\
\hline Fertilization (A)x("F") & 5 & $7.47^{* *}$ & $5.26^{* *}$ & $8.79 * *$ & $7.10^{* *}$ & $0.47^{\mathrm{ns}}$ & $1.29^{\mathrm{ns}}$ & $0.43^{\text {ns }}$ \\
\hline Blocks & 3 & $0.56^{\mathrm{ns}}$ & $1.38^{\mathrm{ns}}$ & $0.4^{\mathrm{ns}}$ & $2.11^{\mathrm{ns}}$ & $0.68^{\text {ns }}$ & $0.97^{\text {ns }}$ & $0.38^{\text {ns }}$ \\
\hline MSD & & 2.89 & 10.46 & 124.06 & 11.70 & 19.11 & 6.66 & 2.03 \\
\hline C. V. (\%) & & 11.63 & 13.73 & 15.17 & 15.84 & 11.75 & 7.23 & 8.68 \\
\hline
\end{tabular}

Fertilization exerted a significant influence $(p<0.01)$ on the mean number of fruits, mean fruit mass, production, and yield (Table 2). These results confirm those found in the literature, in which it is possible to notice the influence of organic fertilization on the yield of several species, including vegetables. Oliveira et al. (2007), when evaluating the yield of black pepper as a function of doses of bovine manure, concluded that, for dry pepper production, the dose of $8.9 \mathrm{~kg} \mathrm{plant}^{-1}$ of bovine manure was responsible for the maximum production, corresponding to $793 \mathrm{~g} \mathrm{plant}^{-1}$.
Araújo et al. (2007), when evaluating the fertilization with bovine manure and biofertilizer on bell pepper production, observed that the conventional fertilization presented no significant difference in comparison with the doses of bovine manure and application of biofertilizer, for the analyzed variables. Sediyama et al. (2014) evaluated the nutrition and yield of two cultivars of colored bell pepper fertilized with swine manure and observed that the application of this biofertilizer promotes efficiently-nourished bell pepper plants, with adequate production, and mean yield value 
of $18.02+\mathrm{ha}^{-1}$.

In this perspective, the results obtained indicate that, during plant development, the application of doses of buriti stem and bovine manure, along with the nutrients initially contained on the soil, supplied efficiently the nutritional requirements of the bell pepper crop.

As an important component of production, the number of fruits per plant has a direct influence on crop yield (Araújo et al., 2009). Regarding the number of fruits per plant (Figure 1), it was verified that there was a quadratic response, and through the derivative of the equation, it was observed that the highest number of fruits was 13.01, reached with the application of $23.15 t$ $\mathrm{ha}^{-1}$ of buriti stem, with a gain of $53.05 \%$ in relation to those obtained in the absence of buriti stem. Figure $5 \mathrm{~A}$ exhibits the mean number of fruits for all treatments, and it can be verified that the dose of $30 \mathrm{tha}^{-1}$ and the treatment with manure + mineral fertilizer achieved the highest values compared to the remaining treatments, with means of 13.04 and 13.03, respectively.

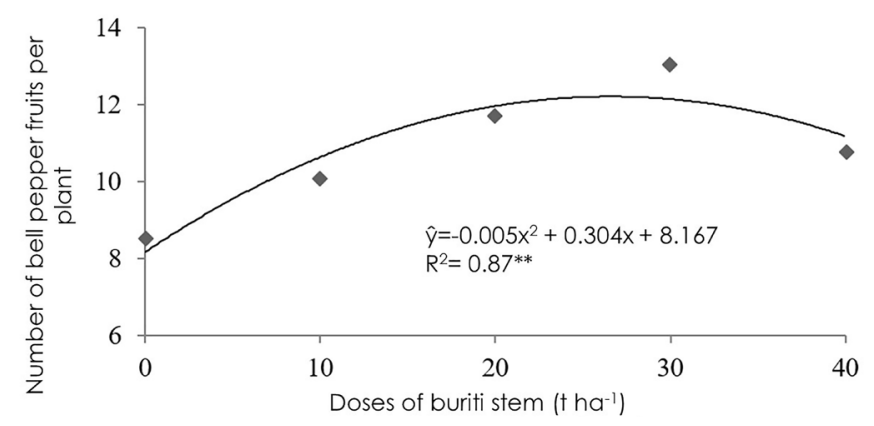

Figure 1. Mean number of bell pepper fruits per plant under the influence of doses of buriti stem.

This result endorses the values obtained by Marcussi \& Villas Bôas (2003), who, when evaluating the efficiency of $N$ and $K$ utilization by bell pepper, under fertigation, obtained a mean of 13 fruits/plant in protected cultivation. It was also above the results obtained by Cardoso (2007), who evaluated bell pepper production under plant vibration, obtaining 10.9 fruits per plant, and 11.6 fruits without vibration, compared to the 10.92 fruits obtained by Santana et al. (2004), working with bell pepper irrigated with different soil water tensions, and to the 10.93 fruits verified by Rocha et al. (2006). Lima Neto et al. (2013), evaluating bell pepper growth and production under different concentrations of biofertilizer and with the use of mulch, observed a significant effect on the number of fruits. The same was observed by Negretti et al. (2010) when evaluating the organic fertilization of the bell pepper cultivar Yolo Wonder in a protected environment, which resulted in a mean of 8.66 fruits per plant.

This demonstrates that the buriti stem was capable of supplying the plant requirements and increasing the number of fruits. Therefore, small farmers who are financially unable to acquire chemical inputs but have access to buriti stem can fertilize the bell pepper with this organic input, reducing the use of chemicals and minimizing the contamination of the environment. The buriti stem used in this experiment, for presenting a low C/N ratio (18.3), according to the analysis performed, showed a rapid release of nutrients into the soil solution, becoming a readily available nutrient source to ensure the development of these plants (Oliveira, 2010; Sediyama et al., 2009). This result allows the use of this material as an alternative source for small and medium bell pepper producers, allowing them to obtain a low-cost input with great quality and providing savings in the consumption of mineral fertilizers (Mello et al., 2000).

Regarding fruit mass, it was verified that there was an effect of the application of doses of buriti stem (Figure 2). It was observed that the dose of $20 \mathrm{tha}^{-1}$ promoted a greater amount of fruit mean mass and that there is a quadratic effect with the increase in mass up to the estimated dose of $24.28 \mathrm{tha}^{-1}$, reaching $37.43 \mathrm{~g}$, a gain of $42.75 \%$ compared to that without the application of buriti stem. Figure 5B exhibits the mean mass of all treatments, and it is noted that the dose of $30 \mathrm{tha}^{-1}$ provided a higher mean mass than the remainder, with a value of $30.2 \mathrm{~g}$, a number $13 \%$ higher than the control. Dominic et al. (2017), when evaluating the effect of the use of high tunnel as a cover and different concentrations of bovine and poultry manure on bell pepper production, obtained mean fruit mass values of $32.1 \mathrm{~g}, 32.3 \mathrm{~g}$, and $102.8 \mathrm{~g}$.

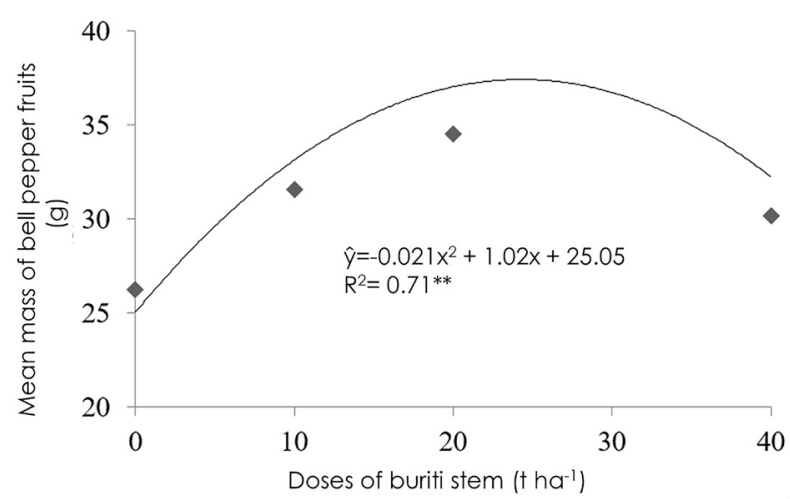

Figure 2. Mean fruit mass of bell pepper fruits under the influence of doses of buriti stem.

Mello et al. (2000) verified that for the mean fruit mass the treatments referring to the addition of organic minerals associated with 70 or $100 \%$ of NPK mineral fertilization did not differ significantly from the application of NPK. Although the doses of buriti stem have influenced the mean fruit mass, the mass of $37.43 \mathrm{~g}$ obtained at the maximum dose of buriti stem, compared to typically 
organic experiments, was below the values found by Charlo et al. (2009) and Ribeiro et al. (2000), who verified a mean fruit mass of $203.35 \mathrm{~g}$ and $72.9 \mathrm{~g}$, respectively, in the treatment with organic fertilization. Temperature is one of the environmental factors that can influence the development of the bell pepper crop (Moreira et al., 2015). This factor may have interfered with fruit development, causing a mean fruit mass below that of other studies. These fruits fall into the category of smallsized fruits (weight below 60 grams) (Roselino et al., 2010). The decrease in the mean mass of fruits as a function of doses of buriti stem above those responsible for the maximum values may indicate that, possibly, the increase in the doses of buriti stem caused a nutritional unbalance and, consequently, a reduction in production.

Regarding the production of fruits per plant (Figure 3), it was noted that there was a quadratic response and that the fertilization at the dose of $20 \mathrm{tha}^{-1}$ resulted in the increase of bell pepper production up to the maximum estimated dose of $25.40 \mathrm{tha}^{-1}$ of buriti stem, with a maximum production of $378.13 \mathrm{~g} \mathrm{plant}^{-1}$, which reflected on yield, with an increment by $42, .22 \%$ in relation the control. Figure $5 \mathrm{C}$ exhibits the production means of each treatment, and it can be seen that treatment $\mathrm{T} 6$ (manure + mineral fertilizer) provided a production mean equal to $471.21 \mathrm{tha}^{-1}$, above the treatments with doses of buriti stem and the control, and not differing statistically from the treatment with the dose of $30 \mathrm{tha}^{-1}$, with a mean of $437.91 \mathrm{tha}^{-1}$. These results are similar to those found by Araújo et al. (2007), in which the estimated dose of $28 t$ $\mathrm{ha}^{-1}$ of bovine manure was responsible for the maximum production of fruits per plant (389 g).

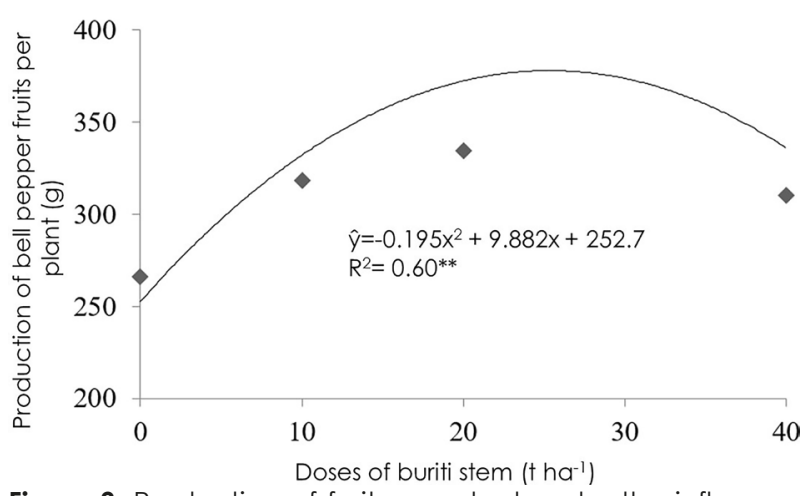

Figure 3. Production of fruits per plant under the influence of doses of buriti stem.

Such results attest to the influence of organic fertilization on production, as already cited by other authors in works with other species. Sousa et al. (2013), studying the use of nitrogen sources and buriti stem in seedlings of Enterolobium contortsiliquum (Vell.) Morong, observed significant quadratic effects with the application of doses of buriti stem on stem diameter and shoot and root dry mass.

Positive effects of the organic fertilization were also reported by Dominic et al. (2017), who, when analyzing the effect of different doses of poultry manure and use of tunnels on bell pepper growth and production, concluded that the application of poultry manure in the concentration of $10 \mathrm{tha}^{-1}$ resulted in better development in bell pepper production and in the dry mass weight. Adhikari et al. (2016), evaluating the effect of the use of different sources of organic and inorganic fertilization, observed that the use of vermicompost increases growth and production in bell pepper compared to the remaining organic fertilizers tested and the chemical fertilizer.

Simillarly, Oliveira et al. (2007) observed a significant effect of bovine manure doses on the production of green and dry pepper per plant, adjusting to the quadratic regression model. Factor et al. (2008) concluded that the fertilization with partial replacement of the mineral fertilizer with a biodigester effluent based on swine waste reached quality standards with good bell pepper yield.

For the yield (Figure 4), it was verified that the application of doses of buriti stem resulted in a quadratic effect, with an increase in yield up to the maximum dose of $22.80 \mathrm{tha}^{-1}$ of buriti stem, reaching a maximum yield of $37.86 \mathrm{tha}^{-1}$, that is, an increase by $62.97 \%$ in relation to the control. Still regarding yield, in Figure 5D it is possible to observe an increase as the doses are reached up to the dose of $30 \mathrm{tha}^{-1}$, which provided a mean of $38.9+\mathrm{ha}^{-1}$. Furthermore, the "manure + mineral fertilizer" treatment has a higher value than the treatment in which the dose of $40 \mathrm{tha}^{-1}$ was used, the highest dose, and the values with doses under $30 \mathrm{tha}^{-1}$, reaching a mean yield of 38,36 $t$ ha $^{-1}$. The effect of organic matter on the production not only of vegetables but also of other plant species is stressed by several researchers, among which Fontanétti et al. (2006), who observed that the use of green manure plus an organic compost allowed to obtain commercial heads of iceberg lettuce and cabbage with satisfactory weight for commercialization. Araújo Neto et al. (2009), when working with bovine manure or earthworm coprolites as nutrient sources and carbonized rice husk as a conditioner, concluded that these could be used in the composition of alternative substrates for the production of bell pepper seedlings, which confirms the importance of the use of organic residues as a nutrient source for horticultural crops.

The yields obtained in this experiment were higher than those of most experiments that used organic fertilizers. The yield is the result of the ability of the plant 


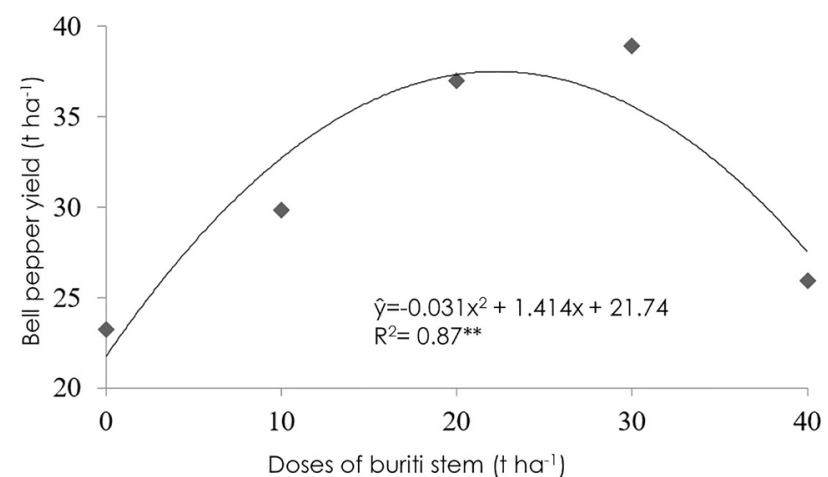

Figure 4. Bell pepper yield under the influence of doses of buriti stem.

in supplying nutrients until the potential limit established for each cultivar. The efficiency of the buriti stem in increasing the bell pepper yield is possibly related to its chemical composition and the improvement provided to the physical and biological properties of the soil through the supply of nutrients, such as nitrogen, phosphorus, and potassium, improving the chemical conditions for plant development.

Generally, the mean yields obtained in the present work surpass most of those found in the literature (Rocha et al., 2006; Factor et al., 2008; Negretti et al., 2010; Carvalho et al., 2011). Araújo et al. (2007), working with biofertilizer in the bell pepper crop applied via soil, obtained a yield of $8.3+\mathrm{ha}^{-1}$ as a function of doses of bovine manure.

Cesar et al. (2007), working with the performance of bell pepper under organic cultivation and subjected to thinning and intercropping, reached a mean yield of $37.1+\mathrm{ha}^{-1}$. On the other hand, Araújo et al. (2007) found significant alterations in the doses of bovine manure, with means of $7.8 \mathrm{tha}^{-1}$, as a function of the use bovine manure, values below those found in the present work. Generally, the bell pepper yield, using doses of buriti stem, was very expressive, although there is still a scarcity of information in the literature regarding the use of this material as an organic fertilizer.
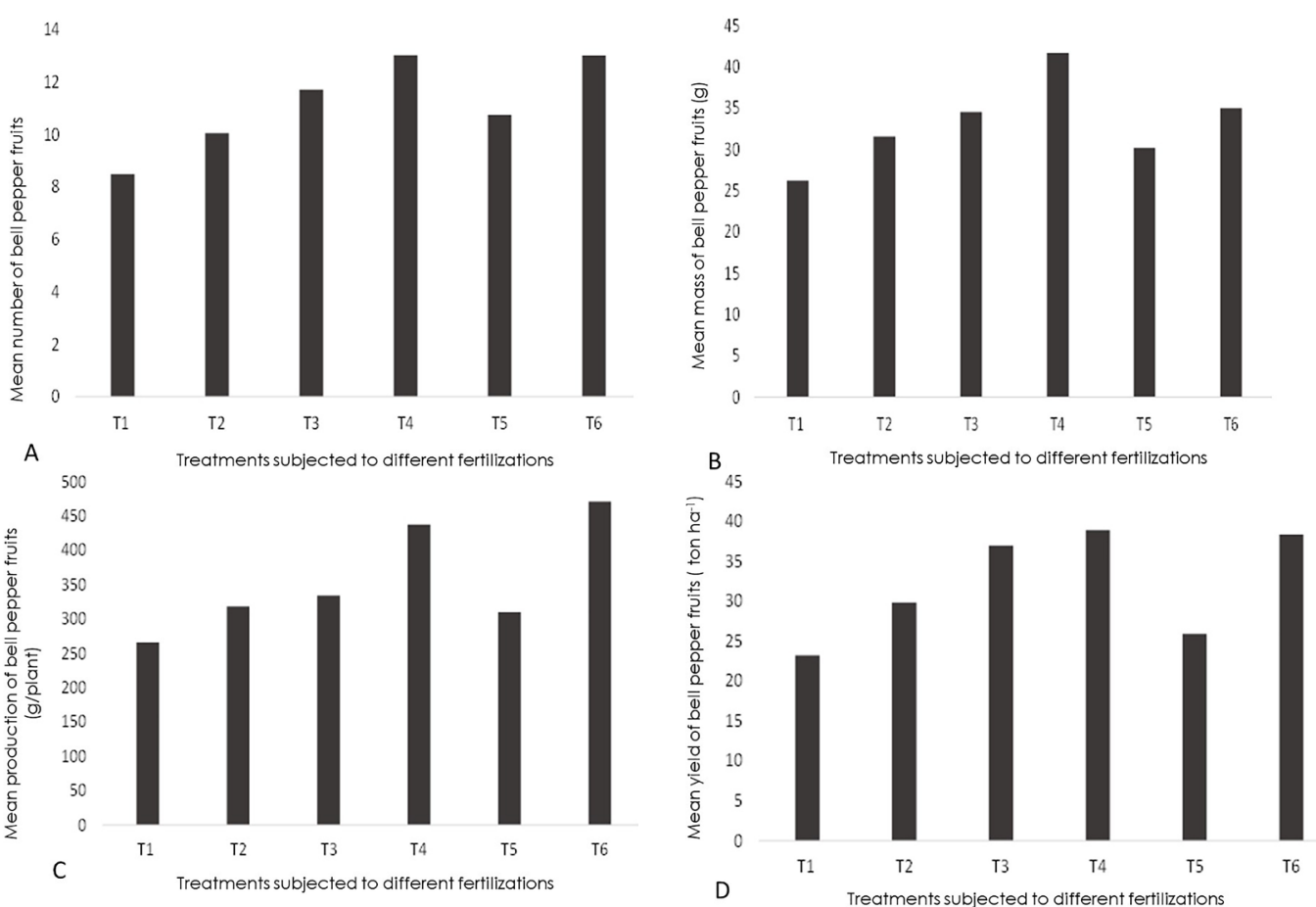

Figure 5. A: Mean number of bell pepper fruits in different fertilizations; B: Mean mass of bell pepper fruits in different fertilizations; C: Mean production of bell pepper fruits in different fertilizations; D: Mean yield of bell pepper fruits in different fertilizations. T1: control; T2: $10+\mathrm{ha}^{-1}$ of buriti stem; T3:20 $\mathrm{h} \mathrm{ha}^{-1}$ of buriti stem; T4: $30 \mathrm{t} \mathrm{ha}^{-1}$ of buriti stem; T5: $40 \mathrm{t} \mathrm{ha}^{-1}$ of buriti stem; T6: manure + mineral fertilization. CV: $11.63 \%, 13.73 \%, 15.17 \%$, and $15.84 \%$ for $A, B, C$, and D, respectively. MSD: $2.89,10.46,124.06$, and 11.7 for $A, B, C$, and $D$, respectively.

\section{Conclusions}

It is concluded that the yield attributes of the bell pepper cv. Casca Dura Ikeda are influenced by organic fertilization, and the doses of $20 \mathrm{tha}^{-1}$ and $30 \dagger$ $\mathrm{ha}^{-1}$ of buriti stem and the use of manure + mineral fertilizer increased the production, mean mass of fruits, yield, and the number of fruits.

\section{Acknowledgments}

The authors thank the CNPq for the research Universal Notice (process $n^{\circ} 481848 / 2011-8$ ). The first author also thanks CAPES for the concession of the master's scholarship. 


\section{References}

Adhikari, P., Khanal, A., Subedi, R. 2016. Effect of different sources of organic manure on growth and yield of sweet pepper. Advances in Plants e Agriculture Research 3: 158161.

Araújo Neto, S.E., Azevedo, J.M.A., Galvão, R.O., Oliveira, E.B.L., Ferreira, R.L.F. 2009. Produção de muda orgânica de pimentão com diferentes substratos. Ciência Rural 39: 1408-1413.

Araújo, E.N., Oliveira, A.P., Cavalcante, L.F., Pereira, W.E., Brito, N.M., Neves, C.M.L., Silva, É.É. 2007. Produção do pimentão adubado com esterco bovino e biofertilizante. Revista Brasileira de Engenharia Agrícola e Ambiental 11: 466-470.

Araújo, J.S., Andrade, A.P., Ramalho, C.I., Azevedo, C.A.V. 2009. Características de frutos de pimentão cultivado em ambiente protegido sob doses de nitrogênio via fertirrigação. Revista Brasileira de Engenharia Agrícola e Ambiental 13: 152-157.

Cardoso, A.I.I. 2007. Produção de pimentão com vibração das plantas. Ciência e Agrotecnologia 31: 1061-1066.

Carvalho, J.A., Resende, F.C., Aquino, R.F., Freitas, W.A., Oliveira, E.C. 2011. Análise produtiva e econômica do pimentão-vermelho irrigado com diferentes lâminas, cultivado em ambiente protegido. Revista Brasileira de Engenharia Agrícola e Ambiental 15: 569-574.

Cesar, M.N.Z., Ribeiro, R.L.D., Paula, P.D., Polidoro, J.C., Manera, T.C., Guerra, J.G.M. 2007. Desempenho do pimentão em cultivo orgânico, submetido ao desbaste e consórcio. Horticultura Brasileira 25: 322-326.

Charlo, H.C.O., Castoldi, R., Fernandes, C., Vargas, P.F., Braz, L.T. 2009. Cultivo de híbridos de pimentão amarelo em fibra da casca de coco. Horticultura Brasileira 27: 155159.

Dominic, I.I., Akpan, N.M., Bayeri, K.P. 2017. Growth and yield responses of green pepper (Capsicum annum L.) to manure rates under field and high tunnel conditions. Notulae Scientia Biologicae 9: 138-142.

Factor, T.L., Araújo, J.A.C., Vilella Júnior, L.V.E. 2008. Produção de pimentão em substratos e fertirrigação com efluente de biodigestor. Revista Brasileira de Engenharia Agrícola e Ambiental 12: 143-149.

Ferreira, P.V. 2000. Estatística experimental aplicada à Agronomia. 3. ed. EDUFAL, Maceió, Brazil. 604 p.

Finger, F.L., Silva, D.J.H. 2005. Cultura do pimentão. In: FONTES, P.C.R. Olericultura: teoria e prática. UFV, Viçosa, Brazil. p. 429-437.

Fontanétti, A., Carvalho, G.J., Gomes, L.A.A., Almeida, K., Moraes, S.R.G., Teixeira, C.M. 2006. Adubação verde na produção orgânica de alface americana e repolho. Horticultura Brasileira 24:146-150.

INMET. Instituto Nacional de Metereologia. 2018. http:// www.inmet.gov.br/portal/<Access on 03 May. 2018>
Jadoski, C.J., Santos, C.M., Rodrigues, J.D., Ono, E.O. 2011 . Ação de reguladores vegetais, controle ambiental e armazenamento sobre parâmetros de conservação do pimentão em pós-colheita. Revista Brasileira de Tecnologia Aplicada nas Ciências Agrárias 4: 99-121.

Khaitov, B., Yun, H.J., Lee, Y., Ruziev, F., Le, T.H., Umurzokov, M., Bo, A., Cho, K.M. Park, K.W. 2019. Impact of Organic Manure on Growth, Nutrient Content and Yield of Chilli Pepper under Various Temperature Environments. International Journal of Environmental Research and Public 16: 3031.

Lima Neto, A.J., Dantas, T.A.G., Cavalcante, L.F., Dias, T.J., Diniz, A.A. 2013. Biofertilizante bovino, cobertura morta e revestimento lateral dos sulcos na produção de pimentão. Revista Caatinga 26: 1-8.

Marcussi, F.F.N., Villas Bôas, R.L. 2003. Marcha de Absorção de Micronutrientes em plantas de pimentão sob fertirrigação em ambiente protegido. Irriga 8: 03-17.

Mello, S.C., Pereira, H.S., Vitti, G.C. 2000. Efeitos de fertilizantes orgânicos na nutrição e produção do pimentão. Horticultura Brasileira 18: 200-203.

Moreira, S.O., Rodrigues, R., Sudré, C.P., Riva-Souza, E.M. 2015. Resistência à mancha-bacteriana e características agronômicas de linhas recombinadas de Capsicum annuum L. Revista Brasileira de Ciências Agrárias 10: 198204.

Negretti, R.R.D., Bini, D.A., Amaral, U., Martins, C.R. 2010. Avaliação da adubação orgânica em pimentão Capsicun annuum cultivado em sistema orgânico de produção sob ambiente protegido. Revista da FZVA 17: $27-37$.

Oliveira, A.P., Alves, E.U., Silva, J.A., Alves, A.U., Oliveira, A.N.P., Leonardo F.A.P., Moura, M.F., Cruz, I. S. 2007. Produtividade da pimenta-do-reino em função de doses de esterco bovino. Horticultura Brasileira 25: 408-410.

Oliveira, F.A., Duarte, S.N., Medeiros, J.F., Oliveira, M.K.T., Silva, R.C.P., Souza M.S. 2016. Eficiência da fertirrigação nitrogenada e potássica na produção de pimentão cultivado em ambiente protegido. Revista de Ciências Agrárias 59: 293-301.

Oliveira, S.A. 2010. Cerrado: Correção do solo e adubação. In: SOUSA, D.M.G., LOBATO, E. Adubação com Nitrogênio. Embrapa Cerrados, Planaltina, Brazil. p. 129- 183.

Resende, I.L.M., Santos, F.P., Chaves, L.J., Nascimento, J.L. 2012. Estrutura etária de populações de Mauritia flexuosa L.F. (Arecaceae) de Veredas da região central de Goiás, Brasil. Revista árvore 36: 103-112.

Ribeiro, L.G., Lopes, J.C., Martins Filho, S., Ramalho, S.S. 2000. Adubação orgânica na produção de pimentão. Horticultura Brasileira 18: 134-137.

Rocha, M.C., Carmo, M.G.F., Polidoro, J.C., Silva, D.A.G., Fernandes, M.C.A. 2006. Características de frutos de pimentão pulverizados com produtos de ação 
bactericida. Horticultura Brasileira 24: 185-189.

Roselino, A.C., Santos, S.A.B., Bego, L.R. 2010. Qualidade dos frutos de pimentão (Capsicum annuum L.) a partir de flores polinizadas por abelhas sem ferrão (Melipona quadrifasciata anthidioides Lepeletier 1836 e Melipona scutellaris Latreille 1811) sob cultivo protegido. Revista Brasileira de Biociências 8: 154-158.

Santana, M.J., Carvalho, J.A., Faquin, V., Queiroz, T.M. 2004. Produção do pimentão (Capsicum annuum L.) irrigado sob diferentes tensões de água no solo e doses de cálcio. Ciência e Agrotecnologia 28: 1385-1391.

Sediyama, M.A.N., Vidigal, S.M., Santos, M.R., Salgado, L.T. 2009. Rendimento de pimentão em função da adubação orgânica e mineral. Horticultura Brasileira 27: 294-299.

Sediyama, M.A.N., Santos, M.R., Vidigal, S.M., Pinto, C.L.O. Jacob, L.L. 2014. Nutrição e produtividade de plantas de pimentão colorido, adubadas com biofertilizante de suíno. Revista Brasileira de Engenharia Agrícola e Ambiental 18: 588-594.

Silva, F.A.S., Azevedo, C.A.V. 2002. Versão do programa computacional Assistat para o sistema operacional Windows. Revista Brasileira de Produtos Agroindustriais 4: 71-78,

Sousa, W.C., Nóbrega, R.S.A., Nóbrega, J.C.A., Brito, D.R.S., Moreira, F.M.S. 2013. Fontes de nitrogênio e caule decomposto de Mauritia flexuosa na nodulação e crescimento de Enterolobium contortsiliquum. Revista Árvore 37: 969-979.

Conflict of Interest Statement: The authors declare that the research was conducted in the absence of any commercial or financial relationships that could be construed as a potential conflict of interest.

All the contents of this journal, except where otherwise noted, is licensed under a Creative Commons Attribution License attribuition-type BY. 